\title{
Structural Analysis of Depression Indicators Scale-Children and Adolescents (BAID-IJ): A Bifactor-ESEM Approach
}

\author{
Lisandra Borges ${ }^{1}$ \\ Makilim Nunes Baptista \\ Universidade São Francisco, Itatiba, São Paulo, Brazil \\ Alexandre Luiz de Oliveira Serpa \\ Universidade São Francisco, Itatiba, SP, Brazil \\ Hogrefe Cetepp, São Paulo, SP, Brazil
}

\begin{abstract}
Depression in children and adolescents has reached alarming levels, evidencing an ever-greater need for early diagnosis of the disorder. Depression is a construct closely related to other indicators and the broad track of symptoms. The Depression Indicator Assessment Battery was developed to measure the core symptoms of depression, loneliness, helplessness, self-esteem and self-concept. Participants were 976 children and adolescents, aged 8-18 years. The data was collect from two public schools and from public mental health care services in Brazil. The internal structure was studied with the comparison of six different exploratory and confirmatory models, each one nest different assumptions. The comparison of models indicated that a latent bifactor explanatory structural equation model better explains the variance of data. The latent structure expected for the battery was confirmed, taking in account the complexity of measure correlated constructs, linking the theory to the measure.
\end{abstract}

Keyword: Psychometric, psychological assessment, childhood depression.

\section{Análise Estrutural da Bateria de Avaliação de Indicadores de Depresão Infantojunenil: Uma Abordagem ESEM Bifactor}

\section{Resumo}

A depressão em crianças e adolescentes tem atingido níveis alarmantes, evidenciando uma necessidade cada vez maior para o diagnóstico precoce da doença. A depressão é um construto intimamente relacionado com indicadores e uma ampla faixa de sintomas. A Bateria de Avaliação de Indicadores de Depressão Infantojuvenil (BAID-IJ) foi desenvolvido para medir os sintomas nucleares da depressão, solidão, desamparo, a autoestima e autoconceito. Participaram da pesquisa 976 crianças e adolescentes de 8-18 anos. Os dados foram coletados a partir de duas escolas públicas e de serviços públicos de saúde mental no Brasil. A estrutura interna foi estudada com a comparação de seis diferentes modelos exploratórios e confirmatórios. A comparação entre os modelos indicou que a modelagem de equação estrutural do fator latente exlicou melhor a variância dos dados. A estrutura latente prevista para a bateria foi confirmada, levando em conta a complexidade da medida correlacionada construções, ligando a teoria à medida.

Palavras-chave: Psicometrica, avaliação psicológica, depressão infantil.

Mailing address: Universidade São Francisco, Av. Senador Lacerda Franco, 360, Itatiba, SP, Brasil, 13251900. E-mail: lisandra.borges@usf.edu.br

Ethical approval and consente CAAE: 0347.0.142.000-11. 


\section{Análisis Estructural de la Depresión Indicadores Niños Escala- y Adolescentes: Un Enfoque Bifactorial-ESEM}

\section{Resumen}

Depresión en niños y adolescentes ha alcanzado niveles alarmantes, lo que evidencia una cada vez mayor necesidad de un diagnóstico precoz de la enfermedad. La depresión es una construcción muy relacionado con otros indicadores y la pista amplia de síntomas. La Batería de Evaluación de Indicadores Depresión fue desarrollado para medir los principales síntomas de la depresión, la soledad, el desamparo, la autoestima y el autoconcepto. Los participantes fueron 976 niños y adolescentes, con edades entre 8-18 años. Los datos fueron cobrar de dos escuelas públicas y de los servicios públicos de salud mental en Brasil. La estructura interna se estudió con la comparación de seis modelos exploratorio y confirmatorio diferentes, cada uno de anidación supuestos diferentes. La comparación de los modelos indica que un modelo latente bifactorial exploratoria estructural ecuación, con un factor general y de cinco factores correlacionados grupos que explican mejor la varianza del instrumento. La estructura latente esperado para la batería se confirmó, teniendo en cuenta la complejidad de la medida correlacionada construcciones, vinculando la teoría con la medida.

Palabra clave: Psicometría, evaluación psicológica, depresión infantil.

According to the World Health Organization (WHO), depression can affect even very young people, reducing a person's productivity throughout life, and, possibly for this reason, it has become the leading cause of disability worldwide. In some cases, depression may become recurrent or chronic, increasing the daily difficulties, which may ultimately lead a person to commit suicide. Depression is the predominant cause of disability in children/teens aged 10 to 19 years, being among the top three causes of death among adolescents worldwide (WHO, 2014). In light of this information, we advocate for the construction of new psychological tests that can detect depressive symptoms in these population.

The Depression Indicators Assessment Battery-Children and Adolescents (BAID-IJ) was constructed based on the depression diagnosis criteria established by the DSM-5, considering the studies of Weinberg, Rutman, Sullivan, Pencik, and Dietz (1973) for depression; the theories of Hymel, Tarulli, Hayden Thomson, and Terrell-Deutsch (1999) for loneliness; Abransom, Seligman, and Teasdale (1978) for helplessness; Coopersmith (1967) for selfesteem; and the multidimensional model of Harter (1996) for self-concept. The proposed battery of scales aims to measure indicators of depression, loneliness, helplessness, self-esteem, and self-concept in children and adolescents of ages 8-18 years old.

Reise, Moore, and Haviland (2011) indicate that depression could be considered a complex construct and evaluate dimensionality and interpret such data can be an intricate task. Psychological measurements can often result in item responses that are consistent as well as one-dimensional (a single common factor), as multidimensional latent structures (which are usually resulting from similar content items).

Several approaches could help to address this complexity. For Simms, Grös, Watson, and O'Hara (2007), hierarchical models suggest that both components, general and specific, are necessary to full representate of the variation observed between mood disorders and anxiety. Furthermore, bifactor models specifie that there is no single general trait that explains the variance, but there are some groups of additional traits that explain the common variance in the subscales and are an alternative to non-hierarchical multidimensional constructs (Reise, Morizot, \& Hays, 2007).

The aim of this study is to examine the internal structure of BAID-IJ comparing five models 
structural models with different assumptions. The results will be evaluate in terms of theoretical and consistency regarding the construct measured.

\section{Method}

\section{Participants}

The study included 976 children and adolescents, aged 8-18 years old $(M=15.16 ; S D=2.867)$, and the majority was female $(n=516 ; 53 \%)$. The sample was composed by children and adolescents from a mental health outpatient service, a health clinic - each of those in psychotherapeutic care had complained of emotional difficulties -, a shelter and for two public schools in the state of Minas Gerais, Brazil.

\section{Instruments}

Depression Indicator Assessment BatteryChildren and Adolescents (BAID-IJ; Borges, Baptista, \& Serpa, 2015). The BAID-IJ contains 91 items and assess depression (20), loneliness (17), helplessness (17), self-esteem (19) and self-concept (18). Examinee is asked to take into account his/her thoughts, feelings and behavior in the last 15 days. The items of depression, loneliness and helplessness were constructed prioritizing negative feelings, thoughts and behaviours; and the items of self-esteem and self-concept were constructed with references to positive characteristics.

\section{Procedure}

The project was submitted and approved by the Research Ethics Committee and the parents and/or guardians agreed to the participation of the children and adolescent in the research. Data collection was carried out collectively, in the classroom and during hours previously scheduled with the school administration. For the children aged 8, 9 and 10 years, the items were read aloud to avoid difficulty in comprehension.

The analyses were performed via R software (R Core Team, 2015), using the Psych (Revelle, 2015) and Sampling (Tillé \& Matei, 2013) packages, and Mplus-version 6.11 (Muthén \& Muth- én, 2010). The sample was splitted randomly in two groups with similar demographic characteristics to enable the exploratory and confirmatory analysis.

First, was tested how many factors could explain the test underline structure using the parallel analysis procedure (Horn, 1965), using the polychoric matrix to evaluate the set of items. Second, two factorial analyses were conducted with all items, the first considering a unidimensional structure and the second, a five correlated factor structure, using oblimin rotation. After that, a bifactor exploratory analysis model was performed by structural equation (B-ESEM). This model is less restrictive than the traditional bifactorial model in allowing items to saturate in more than one factor; it is more adequate for correlated group structures (Reise et al., 2011).

In addition, four additional models were designed: one was a confirmatory factor analysis model considering the five uncorrelated latent factors (CFA-5D), one with the five correlated latent factors (CFA-5), a model with the five uncorrelated latent factors and a hierarchical general factor (H-CFA-D); one with the five correlated latent factors and as a hierarchical general factor (H-CFA), and a classic bifactor model (B-Factor) with the Schmid and Leiman orthogonalization method,with five specific factors and one general factor. For all models we used the WLSMV estimator, except for the BESEM when the TARGET rotation was chosen, as recommended by Reise et al. (2011).

\section{Results}

The parallel analysis employed both principal components and principal axis factor analysis as the extraction methods. The graphical analysis lead to the evidence that a factorial structure exists underlying the scale. For all items of the five subscales (depression, loneliness, helplessness, self-esteem and self-concept) was observed a common dimension. The subscales are also unidimensional when observed independently. This result lead us to some question: How do we could interpret this complex structure or address this information in an exploratory model? 
After that, a configural structure from three exploratory models with different assumptions was compared: (a) An unidimensional model underlying all items; (b) a 5-factor analysis, with an oblique configuration; (c) and a B-ESEM model. Table 1 shows the similarity between the factor loadings of the unidimensional model and the general factor of the B-ESEM model. A reasonable recovery of the five factors model could be seen, providing further evidence of a structure similar to B-ESEM.

Table 1

Comparison between Factor Analysis and Bifactor ESEM Models

\begin{tabular}{|c|c|c|c|c|c|c|c|c|c|c|c|c|}
\hline \multirow{2}{*}{ Items } & \multirow{2}{*}{ unidimensional } & \multicolumn{5}{|c|}{ Five Correlated factors } & \multicolumn{6}{|c|}{ B-ESEM (target rotation) } \\
\hline & & $\mathrm{F} 1$ & $\mathrm{~F} 2$ & $\mathrm{~F} 3$ & $\mathrm{~F} 4$ & F5 & G & $\mathrm{F} 1$ & $\mathrm{~F} 2$ & $\mathrm{~F} 3$ & $\mathrm{~F} 4$ & F5 \\
\hline dep1 & 0.34 & 0.42 & & & & & 0.362 & 0.400 & & & & \\
\hline $\operatorname{dep} 2$ & 0.31 & 0.42 & & & & & 0.334 & 0.422 & & & & \\
\hline dep3 & 0.46 & 0.40 & & & & & 0.463 & 0.328 & & & & \\
\hline dep4 & & & & & & & & & & & & \\
\hline $\operatorname{dep} 5$ & 0.40 & 0.51 & & & & & 0.373 & 0.511 & & & & \\
\hline dep6 & 0.52 & 0.57 & & & & & 0.544 & 0.564 & & & & \\
\hline $\operatorname{dep} 7$ & 0.56 & 0.50 & & & & & 0.533 & 0.401 & & & & \\
\hline $\operatorname{dep} 8$ & 0.37 & & & & & 0.40 & 0.427 & & & & -0.362 & \\
\hline dep9 & 0.44 & & & 0.46 & & & 0.474 & & & 0.479 & & \\
\hline dep10 & & & & & & & & & & & & \\
\hline dep11 & 0.35 & 0.40 & & & & & 0.354 & 0.414 & & & & \\
\hline dep12 & 0.53 & & & & & & 0.668 & 0.391 & & & & \\
\hline dep13 & & 0.32 & & & & & & 0.309 & & & & \\
\hline dep14 & 0.46 & & & 0.41 & & & 0.508 & & & 0.363 & & \\
\hline dep 15 & 0.34 & & & & & & 0.335 & & & & & \\
\hline dep16 & & 0.41 & & & & & & 0.314 & & & & \\
\hline dep17 & 0.35 & & & & & & 0.378 & & & & & \\
\hline $\operatorname{dep} 18$ & 0.54 & 0.39 & & & & & 0.553 & 0.373 & & & & \\
\hline dep19 & 0.47 & 0.36 & & & & & 0.517 & 0.396 & & & & \\
\hline $\operatorname{dep} 20$ & 0.42 & & & 0.41 & & & 0.451 & & & 0.447 & & \\
\hline lon1 & 0.59 & 0.47 & & 0.32 & & & 0.566 & 0.362 & & & & \\
\hline lon2 & & & & & & & & & 0.465 & & & \\
\hline lon3 & 0.44 & & & 0.52 & & & 0.465 & & & 0.446 & & \\
\hline lon4 & 0.48 & & & 0.45 & & & 0.518 & & -0.311 & 0.505 & & \\
\hline lon5 & 0.38 & & & & & & 0.402 & 0.352 & & & & \\
\hline lon6 & 0.33 & & & & & & 0.378 & & & & & \\
\hline lon7 & 0.37 & & 0.31 & & & & 0.420 & & & & & \\
\hline lon8 & & & & & & & & & 0.480 & & & \\
\hline lon9 & 0.39 & & & 0.62 & & & 0.443 & & & 0.601 & & \\
\hline
\end{tabular}


A Bifactor-ESEM Approach.

\begin{tabular}{|c|c|c|c|c|c|c|c|c|c|c|c|c|}
\hline \multirow{2}{*}{ Items } & \multirow{2}{*}{ unidimensional } & \multicolumn{5}{|c|}{ Five Correlated factors } & \multicolumn{6}{|c|}{ B-ESEM (target rotation) } \\
\hline & & $\mathrm{F} 1$ & $\mathrm{~F} 2$ & F3 & $\mathrm{F} 4$ & F5 & G & $\mathrm{F} 1$ & $\mathrm{~F} 2$ & F3 & $\mathrm{F} 4$ & F5 \\
\hline $\operatorname{lon} 10$ & 0.47 & & & 0.35 & & & 0.524 & & & & & \\
\hline lon11 & 0.54 & & & 0.69 & & & 0.573 & & & 0.588 & & \\
\hline $\operatorname{lon} 12$ & & & & & & & 0.307 & & & & & \\
\hline $\operatorname{lon} 13$ & & & & & & & & & & & & \\
\hline lon14 & 0.47 & & & 0.66 & & & 0.486 & & & 0.651 & & \\
\hline $\operatorname{lon} 15$ & 0.35 & & & 0.67 & & & 0.373 & & & 0.750 & & \\
\hline $\operatorname{lon} 16$ & 0.33 & & & 0.46 & & & 0.412 & & & 0.463 & & \\
\hline lon17 & & & & & & & & & & 0.325 & & \\
\hline hell & 0.48 & & & & & & 0.539 & & & & & \\
\hline hel2 & 0.47 & 0.47 & & & & & 0.483 & 0.346 & 0.372 & & & \\
\hline $\operatorname{des} 3$ & 0.35 & & & & & & 0.403 & & & & & \\
\hline hel4 & 0.51 & & & 0.41 & & & 0.593 & & & 0.359 & & \\
\hline hel5 & 0.35 & & & & & & 0.409 & & & & & \\
\hline hel6 & 0.32 & & & & & 0.50 & 0.442 & & & & -0.408 & \\
\hline hel7 & 0.34 & & & & & & 0.423 & & & & & \\
\hline hel8 & & & & & & & & & 0.431 & & & \\
\hline hel9 & & 0.36 & & & & & 0.305 & & 0.511 & & & \\
\hline hel10 & 0.56 & 0.42 & & & & & 0.578 & 0.356 & & & & \\
\hline hel11 & 0.57 & & 0.37 & & & & 0.707 & & & & & \\
\hline hel12 & 0.55 & & & & & & 0.579 & & & & & \\
\hline hel13 & 0.45 & & 0.43 & & & & 0.617 & & & & & \\
\hline hel14 & 0.31 & & 0.36 & & & & 0.373 & & & & & \\
\hline hel15 & 0.56 & & 0.45 & & & & 0.631 & & & & & \\
\hline hel16 & 0.35 & & & & & & 0.407 & & & & & \\
\hline hel17 & 0.51 & & & 0.50 & & & 0.573 & & & 0.379 & & \\
\hline est1 & 0.52 & & & & 0.45 & & 0.571 & & & & & \\
\hline est2 & 0.46 & & & & 0.40 & & 0.566 & & & & & \\
\hline est3 & 0.37 & & & & 0.33 & & 0.477 & & & & & \\
\hline est4 & 0.32 & & & & & & 0.418 & & & & & \\
\hline est5 & 0.46 & & & & 0.36 & & 0.563 & & & & & \\
\hline est6 & 0.63 & & & & 0.73 & & 0.754 & & & & 0.412 & \\
\hline est7 & 0.56 & & & & 0.57 & & 0.639 & & & & & \\
\hline est8 & 0.33 & & & & & & 0.495 & & & & & \\
\hline est9 & 0.51 & & & & 0.46 & & 0.600 & & & & & \\
\hline est10 & 0.56 & & & & 0.71 & & 0.627 & & & & & 0.383 \\
\hline
\end{tabular}




\begin{tabular}{|c|c|c|c|c|c|c|c|c|c|c|c|c|}
\hline \multirow{2}{*}{ Items } & \multirow{2}{*}{ unidimensional } & \multicolumn{5}{|c|}{ Five Correlated factors } & \multicolumn{6}{|c|}{ B-ESEM (target rotation) } \\
\hline & & $\mathrm{F} 1$ & $\mathrm{~F} 2$ & F3 & F4 & F5 & G & $\mathrm{F} 1$ & $\mathrm{~F} 2$ & F3 & F4 & F5 \\
\hline est11 & 0.46 & & & & & 0.61 & 0.623 & & & & -0.320 & \\
\hline est12 & 0.57 & & & 0.33 & & & 0.702 & & & & & \\
\hline est13 & 0.41 & & & & & 0.81 & 0.604 & & & & -0.509 & \\
\hline est14 & 0.42 & & & & & 0.63 & 0.579 & & & & -0.403 & \\
\hline est15 & 0.32 & & & & & 0.52 & 0.457 & & & & -0.324 & \\
\hline est16 & 0.46 & & & & 0.49 & & 0.628 & & & & & \\
\hline est17 & & & & & 0.32 & & 0.354 & & & & & \\
\hline est18 & 0.62 & & & & 0.59 & & 0.762 & & & & & \\
\hline \multicolumn{13}{|l|}{ est19 } \\
\hline con1 & 0.46 & & & & & 0.80 & 0.664 & & & & -0.493 & \\
\hline $\operatorname{con} 2$ & 0.39 & & & & & 0.62 & 0.550 & & & & -0.407 & \\
\hline $\operatorname{con} 3$ & 0.36 & & & & & 0.65 & 0.522 & & & & -0.461 & \\
\hline $\operatorname{con} 4$ & & & & & & 0.49 & 0.470 & -0.340 & & -0.307 & & \\
\hline con5 & 0.34 & & & & 0.39 & & 0.308 & & & & & 0.751 \\
\hline con6 & 0.34 & & & & 0.32 & & 0.325 & & & & & 0.738 \\
\hline $\operatorname{con} 7$ & 0.59 & & & & 0.77 & & 0.640 & & & & & 0.460 \\
\hline con8 & 0.44 & & & & 0.56 & & 0.553 & & & & & 0.390 \\
\hline con 9 & 0.53 & & & 0.33 & & & 0.670 & & & & & \\
\hline con10 & 0.54 & & & 0.47 & & & 0.590 & & & 0.339 & & 0.394 \\
\hline con11 & 0.42 & & & 0.52 & & & 0.472 & & & 0.372 & & 0.370 \\
\hline con12 & 0.32 & & & 0.36 & & & 0.449 & -0.397 & & & & \\
\hline con13 & 0.65 & & & & 0.74 & & 0.767 & & & & 0.395 & \\
\hline con14 & 0.57 & & & & 0.81 & & 0.632 & & & & & 0.485 \\
\hline con15 & & & & & 0.43 & & 0.352 & & & & & \\
\hline \multicolumn{13}{|l|}{ con16 } \\
\hline con17 & 0.36 & & & & & & 0.510 & -0.304 & & & & \\
\hline con18 & & & & & & 0.55 & 0.406 & & & & & \\
\hline $\begin{array}{l}\text { Explained } \\
\text { Variance }\end{array}$ & 0.18 & & & & & & & & & & & \\
\hline
\end{tabular}

Note. $\mathrm{G}=$ general factor; $\mathrm{F} 1 / \mathrm{DEP}=$ depression; F2/HEL = helplessness; F3/SOL = loneliness; F4/EST = self-esteem; F5/CON $=$ self-concept.

In a second step, was build concurrent models to take in consideration different assumptions of the latent structure organization of BAID-IJ. As noted in Table 2, among the six models (CFA-5D, CFA-5, H-CFA-D, H-CFA, $\mathrm{B}-\mathrm{ESEM}$ and B-Factor), the B-ESEM model shows the best fit. The B-ESEM shows CFI $=0.950$ and $\mathrm{TLI}=0.942$, and the indices are considered good ( $\mathrm{Hu} \&$ Bentler, 1999). The root mean square of approximation (RMSEA) was to 0.025 [0.023-0.027], which suggests an adequate index. 
Table 2

Model's Goodness of Fit

\begin{tabular}{lcccccc}
\hline Model & $\chi^{2}$ & $d f$ & CFI & TLI & RMSEA & RMSEA 90\% CI \\
\hline CFA-5D & $22716.732^{*}$ & 4026 & 0.200 & 0.186 & 0.098 & {$[0.096-0.099]$} \\
CFA-5 & $16018.267^{*}$ & 4016 & 0.486 & 0.476 & 0.078 & {$[0.077-0.080]$} \\
H-CFA-D & $8783.497^{*}$ & 3999 & 0.796 & 0.791 & 0.050 & {$[0.048-0.051]$} \\
H-CFA & $7655.149^{*}$ & 3995 & 0.844 & 0.840 & 0.043 & {$[0.042-0.045]$} \\
B-Factor & $16484.932^{*}$ & 3946 & 0.399 & 0.376 & 0.081 & {$[0.079-0.082]$} \\
B-ESEM & $4611.187^{*}$ & 3560 & 0.950 & 0.942 & 0.025 & {$[0.023-0.027]$} \\
\hline
\end{tabular}

${ }^{*} p=.001$

\section{Discussion}

First, it is important to emphasize some advantages of using the bifactor model (Reise et al., 2011). This model allows researchers to measure individuals on a single trait and control the distorting effects of multidimensionality caused by, for example bias in items or nonmodelled psychological constructs, regarding differences in the groups. Also, it enables the study on the contribution of general factors and external variables groups and the comparison between unidimensional and multidimensional models to evaluate distortions in the estimates of the model.

Results showed that the BAID-IJ has a complex structure and an underlying latent trait to all scales. Theoretically, the general factor can be interpreted as a general latent trait underlying the constructs and is correlated with depression, loneliness, helplessness, selfesteem and self-concept (American Psychiatric Association [APA], 2014; Seligman, 1967; Weinberg et al. 1973). The descriptors of depression used for the diagnosis of depression in children and adolescents are not clearly defined in literature such as the DSM-5 (APA, 2014), which uses the same diagnostic criteria in adults, stressing only two specific descriptors to the youth population (irritability and unexpected weight based on age).

The results showed at table 1 that some items charged positively at general factor ands positively and negatively at specific factors. It is possible to understand that the item explains the general factor "depression", its specific factor and also is related with other construtos. Depression is deeply linked to other construtos, even positively as negatively and this theoretical union demands efforts to be dismembered. For example, item lon4 "I prefer to be alone at familiar meeting" received positive loading at general factor, negative loadings at F2 (helplessness) and positive at F3 (loneliness). In other words, the item represents depression and loneliness, but, it is possible to understand that loneliness is theoretically related with helplessness. New collects with new samples and similar analysis will be necessary to assess if loadings keep the same, besides, other pilot group will be necessary to asses the comprehension of the items is happening in a correct way.

Some items are loaded with two or three different factors, specifically the self-deprecating constructs related to depression (Weinberg et al., 1973), self-esteem and self-concept. Rosenberg (1979) characterized self-esteem as one of the factors that make up the self-concept. Therefore, it is possible to point out that the difficulty of construct definition can often interfere with the analysis, whether from the item construction process or defining the content. The results obtained for this sample raises the question: to what extent are self-esteem and self-concept correlated to depression?

The evidence suggested a latent bifactor structure for the BAID-IJ. However, according theory, the subscales are not independent and the 
adoption of a conventional bifactor model would not attend to the theoretical criteria and statistical adjustment. The Bifactor-ESEM model relaxes the assumption of group independence and admits the correlation between them, moddeling the variance distribution of the items as a function of conceptual proximity among the constructs. It is important to highlight that this was a preliminary study of the battery and is not yet conclusive. The authors intend to include the measurement scales of hopelessness and self-efficacy in BAID-IJ, understanding the importance of the relationship between these constructs and depression.

\section{References}

Abramson, L. Y., Seligman, M. E. P., \& Teasdale, J. D. (1978). Learned helplessness in humans: Critique and reformulation. Journal of Ab-normal Psychology, 87, 49-74.

American Psychiatric Association. (2014). Manual de diagnóstico e estatística dos distúrbios mentais (DSM 5). Porto Alegre, RS: Artes Médicas.

Borges, L. S., Baptista, M. N., \& Serpa, A. L. O. (2015). Bateria de Avaliação de Indicadores de Depressão Infantojuvenil BAID-IJ (Unpublished Technical Report, Universidade São Francisco, Itatiba, SP, Brazil).

Coopersmith, S. (1967). The antecedents of self-esteem. San Francisco, CA: Freeman.

Harter, S. (1996). Historical roots of contemporary issues involving selfconcept. In B. A. Bracken (Ed.), Handbook of self-concept developmental, social, and clinical considerations (pp. 1-37). New York: Wiley.

Horn, J. L. (1965). A rationale and test for the number of factors in factor analysis. Psychometrika, 30, 179-185.

Hu, L. T., \& Bentler, P. M. (1999). Cutoff criteria for fit indexes in covariance structure analysis: Conventional criteria versus new alternatives, Structural Equation Modeling, 6(1), 1-55.

Hymel, S., Tarulli, D., Hayden Thomsom, L., \& Terrel-Deutsch, B. (1999). Loneliness through the eyes of children. In K. J. Rotenberg \& S. Hymel (Eds.). Loneliness in childhood and adolescence (pp. 80-106). Cambridge, UK: Cambridge Universit Press.
Muthén, L. K., \& Muthén, B. O. (2010). Mplus User's Guide ( $6^{\text {th }}$ ed.). Los Angeles, CA: Muthén \& Muthén.

R Core Team. (2015). R: A language and environment for statistical computing. R Foundation for Statistical Computing, Vienna, Austria.

Reise, S. P., Moore, T. M., \& Haviland, M. G. (2011). Bifactor models and rotations: Exploring the extent to which multidimensional data yield univocal scale scores. Journal of Personality Assessment, 92(6), 544-559.

Reise, S. P., Morizot, J., \& Hays, R. D. (2007). The role of the bifactor model in resolving dimensionality issues in health outcomes measures. Medical Care, 16, 19-31.

Revelle, W. (2015). Psych: Procedures for Personality and Psychological Research, Evanston, IL: Northwestern University.

Rosemberg, M. (1979). Conceiving the Self. New York: Basic Books.

Seligman, M. E. P., \& Maier, S. F. (1967). Failure to escape traumatic shock. Journal of Experimental Psychology, 74, 1-9.

Simms, L. J., Grös, M. A., Watson, D., \& O'Hara, W. (2007). Parsing the general and specific componentes of depression and anxiety with bifactor modeling. Depression an Anxiety, 25(7), 34-46.

Tillé, Y., \& Matei, A. (2013). Sampling: Survey Sampling. $R$ package version 2.6. Retrieved from http://cran.r-project.org/web/packages/sampling/sampling.pdf

Weinberg, W. A., Rutman, J., Sullivan, L., Pencik, E. C., \& Dietz, S. G. (1973). Depression in children referred to an education diagnostic center. Journal of Pediatrics, 83, 1065-1072.

World Health Organization. (2014). A global public health concern. Retrieved from http:// www.who.int/mental_health/management/depression/who paper depression wfmh_2012.pdf 